\title{
COMPARATIVE STUDIES OF SERUM POLYSACCHARIDES IN RHEUMATOID ARTHRITIS AND DEGENERATIVE JOINT DISEASE
}

\author{
By M. R. SHETLAR, R. W. PAYNE, JANE A. BULLOCK, D. R. PATRICK, \\ ARTHUR A. HELLBAUM, AND WILLIAM K. ISHMAEL
(From the Departments of Biochemistry, Pharmacology, and Medicine, University of Oklahoma
School of Medicine, the Research Laboratory of the Veterans Administration Hospital, and the Oklahoma Medical Research Foundation, Oklahoma City, Okla.)

(Submitted for publication June 16, 1953; accepted August 3, 1953)

The origin, physiological role, and metabolism of the serum polysaccharides are largely unknown, and their relationship to changes which occur in connective tissue is not yet firmly established. The occurrence of polysaccharide material in connective tissue has been amply demonstrated by isolation and histochemical methods. Using histochemical methods, an increase of polysaccharide in connective tissue has been noted in many diseases of connective tissue including rheumatic fever, rheumatoid arthritis, and disseminated lupus erythymatosus. Ehrich (1) has recently reviewed the present knowledge of this field. The presence of increased concentrations of polysaccharides in the sera of patients suffering from rheumatic fever (2) and rheumatoid arthritis (3) suggests a possible relationship between serum and tissue polysaccharides in these diseases. Ludwig, Boas, and Soffer (4) demonstrated a possible relationship of connective tissue to serum polysaccharide by showing that an elevation of both the hexosamine of retrobulbular tissue and plasma hexosamine occurred in thyroidectomized guinea pigs after administration of thyrotropic hormone. Catchpole (5) suggests that increased circulating glycoproteins in the blood of tumor animals arise from the ground substance at the site of the invasive growth by a process of depolymerization of tissue glycoprotein. The present study is a more complete analysis of the characteristics of these serum components in rheumatoid arthritis, certain other mesenchymal diseases, and degenerative arthritis, permitting evaluation of the use of serum polysaccharide concentration as a diagnostic aid in differentiating these diseases.

\section{METHODS}

The patients described were seen in the arthritis clinic of the University Hospitals. Serum albumin, pseudo- globulin, and euglobulin were fractionated by a modified method of Milne (6) using 21.5 per cent and 26.8 per cent sodium sulfate. Albumin was assumed to be that portion of serum protein which was not precipitated by 26.8 per cent sodium sulfate; euglobulin, that portion which precipitated with 21.6 per cent sodium sulfate; and pseudoglobulin, the difference between the portion precipitated by 26.8 per cent and that precipitated by 21.5 per cent sodium sulfate. Kingsley's method (7) using ethyl ether for the separation of globulin fractions was used for both levels of sodium sulfate. The biuret reagent as described by Weichselbaum and Shapiro (8) was used for the determination of the total serum protein and protein fractions. Mucoprotein was precipitated from sera by the method of Winzler, Devor, Mehl, and Smyth (9). The hexose components of the polysaccharides of each fraction were determined by the tryptophan method of Shetlar, Foster, and Everett (10). As hexosamine does not develop color with tryptophan in this reaction, the method allows an estimate of polysaccharide components other than hexosamine. For simplicity, results obtained by this method will be referred to as "polysaccharide" in this paper. $\gamma$-globulin was determined by the method of Jager and Nickerson (11). One hour erythrocyte sedimentation rates (Wintrobe) were conducted by the clinical laboratories of the University Hospitals. The clinical diagnosis was established after several visits to the arthritis clinic where the patient was studied by at least two of the clinical members of the staff. Cases of rheumatoid arthritis were classified as (a) active, if evidence of both joint deformity and moderate or severe joint activity was noted; (b) inactive, if joint deformity, but no activity was present; and (c) early (mild), if no joint deformity, but mild activity was noted.

\section{RESULTS}

\section{Serum polysaccharides}

Data resulting from the analysis of total serum polysaccharide and mucoprotein are presented graphically in Figure 1. The elevation of serum polysaccharide may be due simply to an increase in serum protein or to an increase of one or more polysaccharide rich protein fractions. To correct for this effect, polysaccharide contents of each frac- 


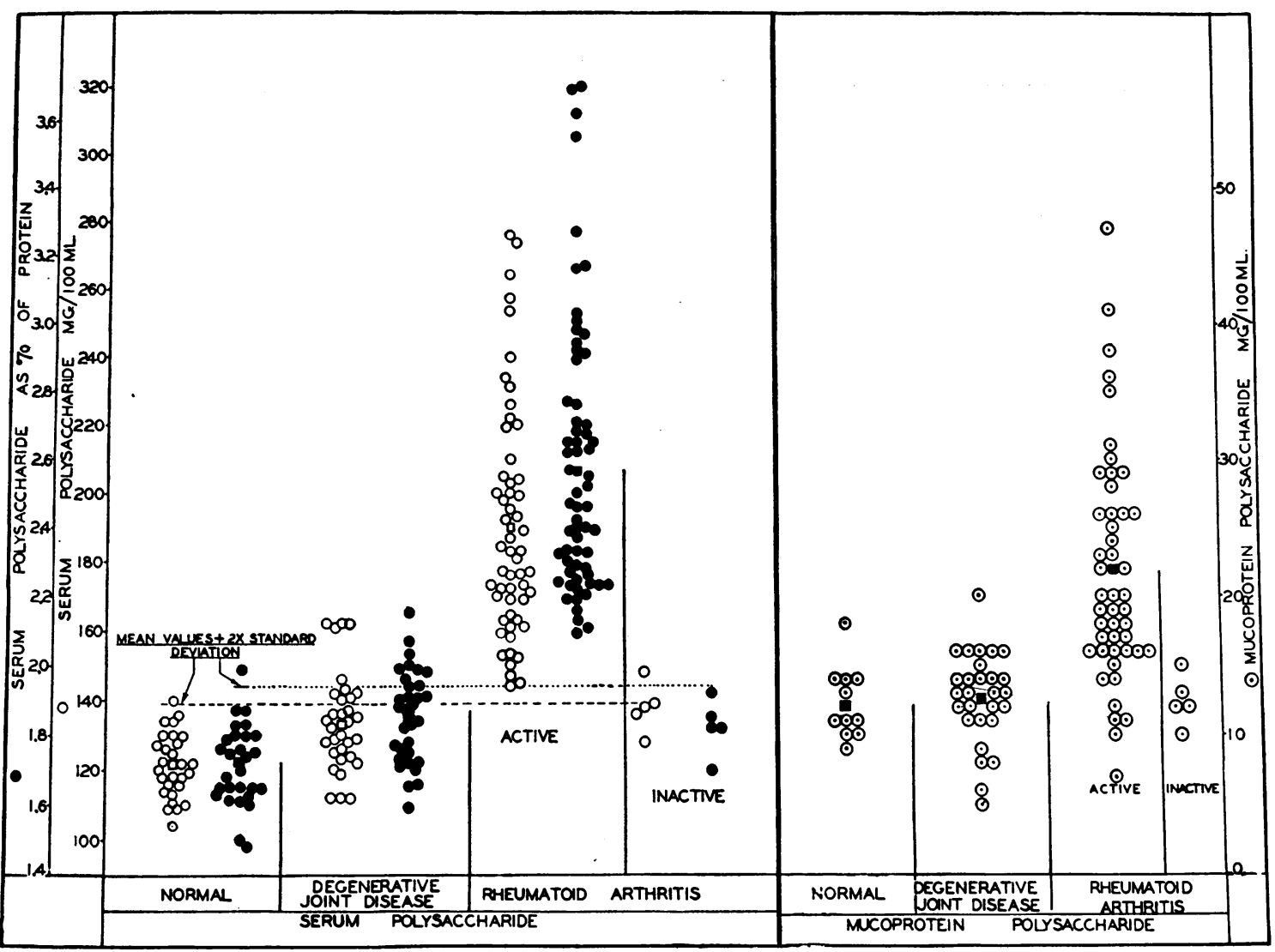

Fig. 1. Total and Mucoprotein Polysaccharides of Serum in Normal Subjects and in Patients with Degenerative Joint Disease and with Rheumatoid Arthritis

Polysaccharide components exclusive of hexosamine expressed as milligrams per $100 \mathrm{ml}$. of serum are shown as open circles, while the polysaccharides expressed as a percentage of serum protein are shown as closed circles. Mucoprotein polysaccharide exclusive of the hexosamine is expressed as milligrams per $100 \mathrm{ml}$. of serum and shown as open circles with a black center. The square in each group represents the average figure for the group.

tion are expressed as percentages of the corresponding protein components and summarized in Table I.

In a preliminary experiment, a known amount of mucoprotein ${ }^{2}$ isolated by the method of Winzler, Devor, Mehl, and Smyth (9) was added to an aliquot of previously analyzed human serum. The serum was then fractionated with 26 per cent sodium sulfate as described above. Results were as follows in $\mathrm{mg}$. per $100 \mathrm{ml}$. of serum :

\begin{tabular}{lcccc} 
& \multicolumn{4}{c}{ Polysaccharide of } \\
\cline { 2 - 5 } & Total & Albumin & $\begin{array}{c}\text { Pseudo- } \\
\text { globulin }\end{array}$ & $\begin{array}{c}\text { Muco- } \\
\text { protein }\end{array}$ \\
Serum & 108 & 25 & 17 & 12 \\
Serum +Mucoprotein & $\frac{125}{17}$ & $\frac{42}{17}$ & $\frac{20}{3}$ & $\frac{30}{18}$
\end{tabular}

${ }^{2}$ Supplied by Dr. Richard J. Winzler, Department of Biological Chemistry, Univ. Illinois College of Medicine.
Apparently in the fractionation procedure with sodium sulfate as described above most of the mucoprotein is included in the albumin fraction. Consequently, results for the albumin polysaccharide were corrected by subtracting the mucoprotein polysaccharide from the original results.

The data were subjected to statistical analysis using the " $t$ " test, where

$$
\mathrm{t}=\frac{\overline{\mathrm{x}}_{2}-\overline{\mathrm{x}}_{1}}{\mathrm{~S} . \mathrm{E} .}, \overline{\mathrm{x}}_{1} \text { and } \overline{\mathrm{x}}_{2}
$$

are means of the two groups being compared, and S.E. is the standard error of the difference of two means. For groups of 28 or more, the standard error was calculated by the formula:

$$
\text { S.E. }=\left(\frac{\sigma_{1}^{2}}{N_{1}}+\frac{\sigma_{2}^{2}}{N_{2}}\right)
$$


TABLE I

Percentage* of serum polysaccharide in serum protein fractions

\begin{tabular}{|c|c|c|c|c|c|c|c|c|c|c|c|}
\hline & \multirow{3}{*}{$\begin{array}{c}\text { No. of } \\
\text { cases }\end{array}$} & \multicolumn{10}{|c|}{ Polysaccharide of } \\
\hline & & \multicolumn{2}{|c|}{ Total protein } & \multicolumn{2}{|l|}{ Albumin } & \multicolumn{2}{|c|}{ Pseudoglobulin } & \multicolumn{2}{|c|}{ Mucoprotein } & \multicolumn{2}{|c|}{ Corrected albumin } \\
\hline & & Average & S.E. & Average & S.E. & Average & S.E. & Average & S.E. & Average & S.E. \\
\hline Normal & 28 & $\begin{array}{c}1.71 \\
(1.48-1.95)\end{array}$ & .021 & $\begin{array}{c}0.65 \\
(0.45-0.82)\end{array}$ & .017 & $\begin{array}{c}2.89 \\
(1.89-4.22)\end{array}$ & 0.11 & $(8-18)$ & 0.8 & $\begin{array}{c}0.40 \\
(0.28-0.55)\end{array}$ & .07 \\
\hline Aged normal & 15 & $\begin{array}{c}1.79 \\
(1.62-2.06)\end{array}$ & .025 & - & & - & & - & & - & \\
\hline $\begin{array}{l}\text { Degenerative } \\
\text { joint disease }\end{array}$ & 28 & $\begin{array}{c}1.85 \\
(1.59-2.15)\end{array}$ & .023 & $\begin{array}{l}0.77 \\
(0.56-1.10)\end{array}$ & .028 & $\begin{array}{c}2.88 \\
(1.84-4.15)\end{array}$ & 0.11 & $\stackrel{13}{(6-16)}$ & 0.6 & $\begin{array}{c}0.47 \\
(0.20-0.72)\end{array}$ & .03 \\
\hline $\begin{array}{l}\text { Rheumatoid ar- } \\
\text { thritis, active }\end{array}$ & 62 & $\begin{array}{c}2.57 \\
(2.09-3.56)\end{array}$ & .051 & $\begin{array}{c}1.38 \\
(0.72-2.73)\end{array}$ & .059 & $\begin{array}{c}4.14 \\
(1.80-7.74)\end{array}$ & 0.18 & $\begin{array}{c}22 \\
(11-47)\end{array}$ & 1.2 & $\begin{array}{c}0.74 \\
(0.41-1.47)\end{array}$ & .04 \\
\hline Inactive & 5 & $\begin{array}{c}1.82 \\
(1.70-1.92)\end{array}$ & .032 & $\begin{array}{c}0.65 \\
(0.59-0.77)\end{array}$ & .036 & $\begin{array}{c}3.42 \\
(2.73-4.30)\end{array}$ & 0.21 & $\begin{array}{c}12 \\
(12-13)\end{array}$ & 0.1 & $\begin{array}{c}0.34 \\
(0.30-0.37)\end{array}$ & \\
\hline Early & 9 & $\begin{array}{c}2.03 \\
(1.70-2.27)\end{array}$ & .067 & $\begin{array}{c}0.77 \\
(0.55-0.97)\end{array}$ & .016 & $\begin{array}{c}3.20 \\
(2.70-4.40)\end{array}$ & 0.10 & $\begin{array}{l}15 \\
(9-20)\end{array}$ & 1.3 & $\begin{array}{c}0.43 \\
(0.28-0.62)\end{array}$ & .04 \\
\hline $\begin{array}{l}\text { Rheumatoid } \\
\text { spondylitis }\end{array}$ & 13 & $\begin{array}{c}1.90 \\
(1.52-2.29)\end{array}$ & .061 & $\begin{array}{c}0.68 \\
(0.48-0.92)\end{array}$ & .041 & $\begin{array}{c}3.50 \\
(2.57-4.80)\end{array}$ & 0.16 & $\begin{array}{c}14 \\
(9-19)\end{array}$ & 0.1 & $\begin{array}{c}0.35 \\
(0.26-0.44)\end{array}$ & .02 \\
\hline Mixed arthritis $\dagger$ & 7 & $\begin{array}{c}2.15 \\
(1.71-2.57)\end{array}$ & .092 & $\begin{array}{c}0.93 \\
(0.80-1.04)\end{array}$ & .046 & $\begin{array}{c}4.96 \\
(3.33-6.35)\end{array}$ & 0.48 & $\begin{array}{c}14 \\
(11-16)\end{array}$ & 1.2 & $\begin{array}{c}0.58 \\
(0.55-0.56)\end{array}$ & \\
\hline Gout, active & 2 & $\begin{array}{c}2.65 \\
(2.44,2.85)\end{array}$ & & $\begin{array}{c}1.30 \\
(1.35,1.45)\end{array}$ & & $\begin{array}{c}3.13 \\
(2.20,4.06)\end{array}$ & & $\begin{array}{c}22 \\
(20,25)\end{array}$ & & $\begin{array}{c}0.86 \\
(0.85,0.87)\end{array}$ & \\
\hline Gout, inactive & 6 & $\begin{array}{c}2.04 \\
(1.91-2.17)\end{array}$ & & $\begin{array}{c}0.77 \\
(0.60-0.89)\end{array}$ & & $\begin{array}{c}3.80 \\
(3.00-4.76)\end{array}$ & & $\begin{array}{c}15 \\
(11-19)\end{array}$ & & $\begin{array}{c}0.43 \\
(0.25-0.52)\end{array}$ & \\
\hline $\begin{array}{l}\text { Psychogenic } \\
\text { rheumatism }\end{array}$ & 3 & $\begin{array}{c}1.72 \\
(1.57-1.99)\end{array}$ & & $\begin{array}{c}0.67 \\
(0.60-0.74)\end{array}$ & & $\begin{array}{c}3.30 \\
(2.47-4.56)\end{array}$ & & $\begin{array}{c}12 \\
(8-18)\end{array}$ & & $\begin{array}{c}0.43 \\
(0.27-0.53)\end{array}$ & \\
\hline Dermatomyositis & 4 & $\begin{array}{c}1.83 \\
(1.77-1.91)\end{array}$ & & $\begin{array}{c}0.68 \\
(0.68-0.69)\end{array}$ & & $\begin{array}{c}3.54 \\
(3.16-3.93)\end{array}$ & & $\begin{array}{c}11 \\
(10-12)\end{array}$ & & $\begin{array}{c}0.42 \\
(0.40-0.52)\end{array}$ & \\
\hline $\begin{array}{l}\text { Lupus erythe- } \\
\text { matosus }\end{array}$ & 1 & 3.40 & & 2.30 & & 5.08 & & 24 & & 1.23 & \\
\hline $\begin{array}{l}\text { Periarteritis } \\
\text { nodosa }\end{array}$ & 1 & 1.91 & & 0.91 & & 3.40 & & 13 & & 0.61 & \\
\hline $\begin{array}{l}\text { Weber Christian } \\
\text { Disease }\end{array}$ & 1 & 2.13 & & 0.81 & & 3.38 & & - & & - & \\
\hline
\end{tabular}

* Polysaccharide of each protein fraction expressed as a percentage of the corresponding protein component. Hexosamine component of the polysaccharide complex is not included.

$\dagger$ Both rheumatoid arthritis and degenerative joint disease present.

where $\sigma_{1}$ and $\sigma_{2}$ are standard deviations for the two groups and $N_{1}$ and $N_{2}$, the number of cases in the respective groups. When less than 28 cases were in either group the following formula was used:

$$
\text { S.E. }=\left(\frac{N_{1}+N_{2}}{N_{1}+N_{2}-2}\right)^{t}\left(\frac{N_{1} \sigma_{1}^{2}+N_{2} \sigma_{2}^{2}}{N_{1} N_{2}}\right)
$$

The results of this statistical analysis are summarized in Table II.

An increase of total albumin, pseudoglobulin, and mucoprotein polysaccharide was noted in the sera of patients (aged 8 to 76 ) with active rheumatoid arthritis. When compared to the patients with degenerative joint disease, highly significant differences between the two groups were noted in all factors. When the degenerative joint disease group (aged 28 to 59) was compared to the normal group (aged 18 to 45 ) a significant elevation of total and albumin polysaccharide was noted in the group with degenerative joint disease. However, when compared to a group of aged normals (over 60 years) no significant differences were 
TABLE II

Summary of statistical comparisons-t values

\begin{tabular}{|c|c|c|c|c|c|}
\hline \multirow[b]{2}{*}{ Comparison } & \multicolumn{5}{|c|}{ Percentage polysaccharide* of } \\
\hline & Total & Albumin & $\begin{array}{l}\text { Pseudo- } \\
\text { globulin }\end{array}$ & $\begin{array}{l}\text { Muco- } \\
\text { protein }\end{array}$ & $\begin{array}{l}\text { Corrected } \\
\text { albumint }\end{array}$ \\
\hline $\begin{array}{l}\text { Rheumatoid A. vs. Degenerative joint disease } \\
\text { Normal vs. Degenerative joint disease } \\
\text { Aged normal vs. Degenerative joint disease } \\
\text { Normal vs. Rheum. spondylitis } \\
\text { Normal vs. Inactive rheumatoid arthritis }\end{array}$ & $\begin{array}{l}11.1 \ddagger \\
3.12 \ddagger \\
1.47 \\
3.58 \ddagger \\
2.04\end{array}$ & $\begin{array}{l}9.40 \ddagger \\
3.25 \ddagger \\
\overline{0.71} \\
0.07\end{array}$ & $\begin{array}{l}6.04 \ddagger \\
0.11 \\
\overline{5.29} \\
4.11 \ddagger\end{array}$ & $\begin{array}{l}7.22 \ddagger \\
0.47 \\
1.31\end{array}$ & $\begin{array}{l}5.22 \ddagger \\
1.37 \\
1.18\end{array}$ \\
\hline
\end{tabular}

* Polysaccharide of each fraction expressed as a percentage of the corresponding protein component.

$\uparrow$ Percentage of polysaccharide in the protein fraction after correction for the mucoprotein.

$\mp$ Significant at the 1 per cent level.

noted. The rheumatoid spondylitis group (aged 20 to 49) was found to have serum polysaccharide levels which were usually within the normal range, although all of this group were in an active phase of the disease. However, considered as a group, significant elevations of total and pseudoglobulin polysaccharide occurred in the rheumatoid spondylitis group. A significant elevation of pseudoglobulin polysaccharide occurred in the patients with inactive rheumatoid arthritis but no other significant differences in this group were noted. Elevations of serum polysaccharides occurred in active gout and disseminated lupus erythematosus, although the number of cases studied was too small to be analyzed statistically. A doubtful elevation was noted in the one case of Weber Christian Disease, while essentially normal values were found in patients with psychogenic rheumatism, dermatomyositis, and periarteritis nodosa (Table I).

\section{Serum proteins}

Summary of the fractionated protein values for patients with rheumatoid arthritis, rheumatoid spondylitis, and degenerative joint disease are given in Table III. These results were treated statistically by the " $t$ " test as described above. Changes were observed in serum proteins as determined by salt fractionations in rheumatoid arthritis patients similar to those previously reported using electrophoretic techniques (12). Both pseudo-( $\alpha$-globulin) and $\gamma$-globulin were found to be significantly increased, while albumin was decreased. Smaller but significant elevations of $\gamma$-globulin were also noted in the patients with rheumatoid spondylitis and with degenerative joint disease. These results are similar to those reported by Effersoe (13) using a polyfractionation saltingout method with ammonium sulfate.

TABLE III

Summary of the serum protein* fractions of arthritis patients as determined by salt fractionation

\begin{tabular}{|c|c|c|c|c|c|c|c|c|}
\hline & \multirow{2}{*}{$\begin{array}{l}\text { No. of } \\
\text { cases }\end{array}$} & \multirow[b]{2}{*}{ Total } & \multicolumn{2}{|c|}{ Albumin } & \multirow[b]{2}{*}{ Pseudoglobulin } & \multirow[b]{2}{*}{$\gamma$-Globulin } & \multicolumn{2}{|c|}{ A/G ratio } \\
\hline & & & Howe & Milne & & & Howe & Milne \\
\hline Normal & 28 & $\begin{array}{c}7.08 \\
(6.50-7.73)\end{array}$ & $\begin{array}{c}5.04 \\
(4.47-5.62)\end{array}$ & $\begin{array}{c}4.31 \\
(3.43-5.07)\end{array}$ & $\begin{array}{c}0.73 \\
(.45-1.04)\end{array}$ & $\begin{array}{c}0.92 \\
(.58-1.55)\end{array}$ & 2.47 & 1.55 \\
\hline $\begin{array}{l}\text { Rheumatoid } \\
\text { arthritis, active }\end{array}$ & 54 & $\begin{array}{c}7.46 \dagger \\
(6.13-8.74)\end{array}$ & $\begin{array}{c}4.69 \\
(3.44-5.56)\end{array}$ & $\begin{array}{c}3.78 \ddagger \\
(2.36-4.63)\end{array}$ & $\begin{array}{c}0.91 \dagger \\
(.56-1.59)\end{array}$ & $\begin{array}{c}1.87 \dagger \\
(.81-4.01)\end{array}$ & 1.71 & 1.03 \\
\hline $\begin{array}{l}\text { Degenerative } \\
\text { joint disease }\end{array}$ & 32 & $\begin{array}{c}7.15 \\
(6.16-8.34)\end{array}$ & $\begin{array}{c}4.94 \\
(4.22-5.82)\end{array}$ & $\begin{array}{c}4.09 \\
(3.02-4.82)\end{array}$ & $\begin{array}{c}0.85 \\
(.51-1.12)\end{array}$ & $\begin{array}{c}1.34 \dagger \\
(.67-2.18)\end{array}$ & 2.23 & 1.34 \\
\hline $\begin{array}{l}\text { Rheumatoid } \\
\text { spondylitis }\end{array}$ & 9 & $\begin{array}{c}7.57 \\
(6.74-8.82)\end{array}$ & $\begin{array}{c}5.30 \\
(4.82-6.08)\end{array}$ & $\begin{array}{c}4.59 \\
(3.89-5.44)\end{array}$ & $\begin{array}{c}0.71 \\
(.57-.93)\end{array}$ & $\begin{array}{c}1.47 \dagger \\
(.77-2.01)\end{array}$ & 2.18 & 1.54 \\
\hline
\end{tabular}

* Expressed as grams of protein per $100 \mathrm{ml}$. of serum.

t Significantly higher at the 1 per cent level than the corresponding normal value.

¥ Significantly lower at the 1 per cent level than the corresponding normal value. 


\section{Sedimentation rates}

A summary of erythrocyte sedimentation rates for patients with rheumatoid arthritis, spondylitis, and degenerative joint disease is given in Table IV. Sedimentation rates were generally elevated in the rheumatoid arthritis patients; many of the patients with degenerative joint disease also had elevated sedimentation rates. In order to determine if sedimentation rate and serum polysaccharide concentration reflect similar disease processes in rheumatoid arthritis, the correlation coefficient between these two factors was determined. A correlation coefficient of 0.24 was found between the percentage of polysaccharide in serum protein and the sedimentation rate in patients with rheumatoid arthritis. This coefficient is not statistically significant, that is, it is not significantly different from 0 . Thus, no quantitative relationship appears to exist between these factors in this series. This finding recalls the observation of Seibert, Seibert, Atno, and Campbell (14) to the effect that serum polysaccharides do not significantly correlate with sedimentation rates in a series composed largely of patients with tuberculosis.

\section{DISCUSSION}

Variation in serum polysaccharides in different mesenchymal diseases is somewhat difficult to evaluate. It seems likely that an elevation of serum polysaccharide may be correlated with either tissue injury, tissue proliferation or both. Shetlar (15) has suggested that an elevation of polysaccharide in the pseudoglobulin and mucoprotein fraction correlates with tissue injury and that an elevation of albumin polysaccharide (after correction for mucoprotein) is related to tissue prolifera- tion. According to these postulates, both inflammation and tissue proliferation occur in many rheumatoid arthritis patients, as 20 out of 43 patients had elevations above the highest normal levels in both albumin and pseudoglobulin polysaccharide components. Only one of 32 patients in the degenerative arthritis group was high enough in total polysaccharide to fall within the range of the rheumatoid arthritis group; however, eight of this group had elevated albumin polysaccharide levels and five had elevated pseudoglobulin polysaccharide levels. The uniformly elevated serum polysaccharide level in rheumatoid arthritis suggests that this assay might be of value as an objective test for evaluating the degree of activity in patients with rheumatoid arthritis. This possibility is currently under investigation.

\section{SUM MARY AND CONCLUSIONS}

Comparative polysaccharide studies were made on the sera of patients with rheumatoid arthritis and degenerative joint disease. A limited number of patients with other collagen diseases and with other joint diseases were also studied. The tryptophan method was used to determine the polysaccharide components other than hexosamine of the total serum protein, albumin, pseudoglobulin, and mucoprotein.

Elevations of the polysaccharide of the total protein, albumin, pseudoglobulin, and mucoprotein were found consistently in the sera of patients with rheumatoid arthritis, but not in those with degenerative joint disease. The polysaccharide content of the pseudoglobulin fraction was found to be elevated in inactive rheumatoid arthritis, while other components were unchanged. No significant

TABLE IV

Comparison of serum polysaccharide values with erythrocyte sedimentation rates

\begin{tabular}{lccccc}
\hline \hline & & & \multicolumn{2}{c}{$\begin{array}{c}\text { Erythrocyte sedimentation rate* } \\
\text { (Wintrobe) }\end{array}$} \\
\cline { 3 - 6 } & $\begin{array}{c}\text { No. of } \\
\text { cases }\end{array}$ & Polysaccharidet & Average & $\begin{array}{c}\text { Number } \\
\text { Range }\end{array}$ \\
\hline elevated
\end{tabular}

* Expressed in millimeters per hour.

+ Percentage of polysaccharide not including hexosamine components found in serum protein.

$\ddagger$ Number of patients with sedimentation rates above 15 millimeters per hour. 
correlation between erythrocyte sedimentation rate and the polysaccharide percentage of serum protein was found in rheumatoid arthritis patients.

Elevations of serum polysaccharides were found in two cases of active gout and in one case of lupus erythematosus, while essentially normal levels were noted in a limited number of patients with inactive gout, dermatomyositis, periarteritis nodosa, and Weber Christian Disease. The use of the determination of serum polysaccharide as a diagnostic aid to distinguish degenerative joint disease from rheumatoid arthritis is suggested.

\section{REFERENCES}

1. Ehrich, W. E., Nature of collagen diseases. Am. Heart J., 1952, 43, 121.

2. Shetlar, M. R., Schmidt, H. L., Jr., Lincoln, R. B., DeVore, J. K., Bullock, J. A., and Hellbaum, A. A., Response of the serum polysaccharide fractions following cortisone treatment of patients with rheumatic fever. J. Lab. \& Clin. Med., 1952, 39, 372.

3. Shetlar, M. R., Shetlar, C. L., Richmond, V., and Everett, M. R., The polysaccharide content of serum fractions in carcinoma, arthritis, and infections. Cancer Research, 1950, 10, 681.

4. Ludwig, A. W., Boas, N. F., and Soffer, L. J., Role of mucopolysaccharides in pathogenesis of experimental exophthalmos. Proc. Soc. Exper. Biol. \& Med., 1950, 73, 137.

5. Catchpole, H. R., Serum and tissue glycoproteins in mice bearing transplantable tumors. Proc. Soc. Exper. Biol. \& Med., 1950, 75, 221.
6. Milne, J., Serum protein fractionation: A comparison of sodium sulfate precipitation and electrophoresis. J. Biol. Chem., 1947, 169, 595.

7. Kingsley, G. R., A rapid method for the separation of serum albumin and globulin. J. Biol. Chem., 1940, 133, 731.

8. Weichselbaum, T. E., and Shapiro, I., A rapid and simple method for the determination of salicylic acid in small amounts of blood plasma. Am. J. Clin. Path. (Tech. Section), 1946, 10, 42.

9. Winzler, R. J., Devor, A. W., Mehl, J. W., and Smyth, I. M., Studies on the mucoproteins of human plasma. I. Determination and isolation. J. Clin. Invest., 1948, 27, 609.

10. Shetlar, M. R., Foster, J. V., and Everett, M. R., Determination of serum polysaccharides by the tryptophane reaction. Proc. Soc. Exper. Biol. \& Med., $1948,67,125$.

11. Jager, B. V., and Nickerson, M., A simple quantitative chemical method for estimating $\boldsymbol{\gamma}$-globulin in human serum. J. Biol. Chem., 1948, 173, 683.

12. Gutman, A. B., The Plasma Proteins in Disease. 15. Rheumatoid Arthritis. Advances in Protein Chemistry, New York, Academic Press, Inc., 1948, 4, 218.

13. Effersoe, P., Effect of adrenocorticotropic hormone (ACTH) and cortisone on serum proteins in various diseases. Scandinavian J. Clin. \& Lab. Invest., 1950, 2, 265.

14. Seibert, F. B., Seibert, M. V., Atno, A. J., and Campbell, H. W., Variation in protein and polysaccharide content of sera in the chronic diseases, tuberculosis, sarcoidosis, and carcinoma. J. Clin. Invest., 1947, 26, 90.

15. Shetlar, M. R., The polysaccharides of serum proteins in cancer. Texas Rep. Biol. \& Med., 1952, 10, 228.

\title{
ERRATUM
}

Pulmonary Function in Boeck's Sarcoid, by M. Henry Williams, Jr., J. Clin. Invest., 32: 9, 909, 1953. Table II.

\author{
Ventilation \\ L./min./sq. meter B.S.A. \\ BTPS \\ VE
}

